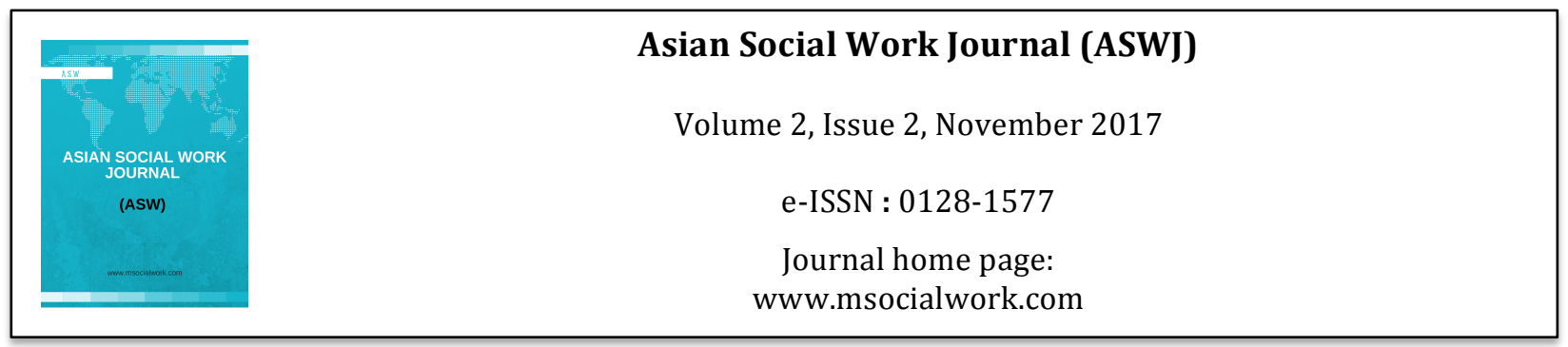

\title{
Psychosocial Therapy Intervention Using Group Work for Women Experiencing Domestic Violence in Indonesia
}

\author{
Meiti Subardhini ${ }^{1}$ \\ 1Bandung College of Social Welfare, Indonesia \\ Corrrespondence: Meiti Subardhini (meiti.subardhini@gmail.com)
}

\begin{abstract}
Issues of Violence are increasing in some recent years, especially in Indonesia, including domestic violence. Victims of this violence will experience psychosocial problems ranging from mild to severe. Therefore, the Social Work profession is relevant to this issue. Previous research had been done to study the practice of Social group work through psychosocial therapy for women experiencing domestic violence, especially at the city of Bandung in West Java, Indonesia. Six (6) study subjects were used as target research through purposive technique. This study used a qualitative approach with action research methods through twelve (12) sessions by using a psychosocial therapy intervention group. Psychosocial problems experienced by members of the group (research subjects) were as follows: behavioral conditions of anxiety, stress and trauma as a result of the violence they experienced resolved through various stages in Social Work with Groups through psychosocial therapy intervention, so the practice of various techniques / psychosocial therapy as part of this study were revealed and described. The results showed that psychosocial therapy interventions group is effective to overcome the domestic violence problem.
\end{abstract}

Key words: psychosocial therapy, domestic violence, intervention, psychosocial, group work

\section{Introduction}

Domestic Violence issue is one of the social problems that have a negative psychosocial impact on women (victims) either physical, psychological and social impacts (Ministry of Social Affairs, 2015). The data of domestic violence victim are increasing every year and as iceberg phenomenon, they aren't seen at the surface. Studies specifically on domestic violence had been carried out by Rifka Annisa Women Crisis Center (RAWCC, 2005), it revealed that $48 \%$ of women (housewives) experienced verbal abuse and $20 \%$ experienced physical violence. Other data indicated by the Commission for Indonesian Women (2005), which stated that $72 \%$ of women who reported the violence, the perpetrator is their husband. Women Crisis Center in Jakarta (2005) showed that 9 out of 10 women as domestic violence victims, experienced more than one type of violence (physical, psychological, sexual, economic and neglect).

Discussing domestic violence cannot be separated from the concept of women. Women as a target or a victim of domestic violence often related to the prevailing value system in society. It is also related to role division between the traditional roles and domestic roles in which women traditional role is an attempt to subordinate women (Savitri Supardi S, 2008). 
If it is associated with the role of women, in other words, works that can be done by woman with her status and position as a woman, it is in accordance with the approach of social work by Barker (1995), defined as feminist social work, i.e. an integration rather than values, skills, and social work knowledge on feminist orientation to assist individuals and communities in addressing social and emotional problems that result from sex discrimination. Therefore, this approach suggests that women victims of domestic violence can be treated by increasing their knowledge and skill.

Bonnie Russell and Max.R.Uhlemann. (2001), suggested that some of the principles that can serve as a guide/base in implementing intervention for victims of domestic violence by a feminist approach, are as following: firstly, it should be viewed "in the socio-political framework". Secondly, sexual roles in traditional view are the pathologies, while the victims of domestic violence need to be encourage to liberate themselves (Howard, April, Stephanie, Riger. Campbell, Rebecca \& Wasco, Sharon. 2003). Thirdly, interventions should be focused in increasing female life, in order to help them getting strength. Fourthly, self-esteem and self-confidence of domestic violence victims must be improved. (Barker, Salvador Minuchin 1985). Fifthly, domestic violence victims should be encouraged to develop their identity (sense of self) by power, brotherhood within a group, their quality and achievements (Barker, Thomas J. Powell 1985). Sixthly: domestic violence victims need to assess and develop a system of social support with other women in order to obtain attention and share their experiences and solutions, seventh, domestic violence victims need to find an effective balance between work and private relationships and eighthly, domestic violence victims gain benefit in learning to express firmness (assertive) themselves for and can be assisted through individual and group counseling (Barker, Dean H. Hepworth and Joan Larsen 1985). The various assumptions above show that women victims of domestic violence desperately need to get interventions related to psychosocial problems they are facing. Some cases that occurred in some countries against women victims of domestic violence and sexual violence programs found that consultation agencies such as counseling bureaus for women victims of domestic violence suggested that psycho-education, shelter and community based counseling for individuals and group, will be an effective model to improve selfesteem, affecting anxiety, depression and hostility, assertiveness, social support, the ability of coping and self efficacy (Cox \& Stoltenberg, 1991; Mancoske, Standifer \& Cauley, 1994; Tutty \& Rothery 1993).

The literatures also mention that the forms of violence experienced by women victims of domestic violence include: physical violence: a behavior deliberately or not deliberately intended to injure or destroy life physically, emotional/psychological violence: the behavior of intentionally traumatizing psychological for others that have unpleasant impact for the victim's personality development, sexual abuse; including rape, forcible sexual contact for showing the action of sexual intercourse against the will of the victim, social violence; an act that limits or endanger the social life of other people individually or collectivity by eliminating or restricting the rights of life, such as restricting access to socialize and communicate with others, social riot and others, as well as economic violence; may include economic exploitation, neglect, abuse, oppression and exploitation by a person or group of people for economic interests. (Howard, April, Stephanie, Riger. Campbell, Rebecca \& Wasco, Sharon. 2003).

The problems evolved are physical, psychiatric/psychological and social, including a mass problem as follows: psychosocial traumatic; it is caused by psychosocial stress occurs when subjected to acts of violence beyond the capabilities of the victim's strength. As a result, they experience social functioning barriers that are characterized by obstacles in carrying out their social roles. Besides, the victim suffered a stress. Schuler (2002) defines that stress is a dynamic condition when a person faced with opportunities, demands, or a source of strength in relation to what is desired by the individual and the result is seen as uncertain and important. Stress is a psychological burden that exceeds the maximum ability of the psyche itself, so the actions are less well controlled. Stress is not always viewed in a negative context. The stress has a positive value when it becomes an opportunity to offer outcome potency, such as the positive challenge to improve the quality of work (Lazarus, R \& Folkman, S. 1984). While Sri Wahyuni 2007, Puji Susilawati 2008, Rifka Anisa 2010 based on the results of their research, said that women victims of domestic violence physically experienced; wounds, fractures, bruises and even death become one of the consequences. Based on the 
above problems then the treatment is done through a variety of approaches, one of them is psychosocial one. Essential element in the psychosocial concerns the idea of the person in situation or person in environment (PIE). In other words, human beings must be understood as the outcome rather than the interaction between the innate bio-genetic, the influence of the significant relationship, the impact of life experiences and participation in social and cultural events (Erickson, 1963; Hollis, 1964; Turner, 1978; Corey, 2005). Therefore, in this study, there were lots of various techniques implementations in psychosocial therapy (Bandura, Fisher \& Gochros, 1979; Ellis, 1989: Corey, 2005 ) to cope with psychosocial problems experienced by victims of domestic violence.

The method of social work with groups became the choice in this study, with assumptions/considerations, as follows: a group is basically formed to satisfy the needs of individuals in overcoming the problems which they handled. Group is considered as an alternative intervention options among others in the social work.

Social Work with a group that became one of important element for focusing in helping members of the group into a system of mutual aid and the main power source of help for each of its members come from members of the group itself. (Zastrow, Charles. Larry E. davis2006). In addition, Social Work with Groups is an activity aimed at raising individual awareness through capacity building by connecting the individual with his group (Konopka, 1992). Other goals of Social Work with groups are as curative, preventive and corrective functions. In detail, giving restorative experience (full restore) and remedial (development), individual and social dysfunction or divisions of individuals in social situations (corrective) are also prevent personal and social divisions where setbacks are harmful (preventive function). Besides, the group can facilitate the process of normal growth and development than other members especially during the certain stressful life. (Elis, Richard M.Tolman \& Christian E 1989). Then in starting the group needs to consider some steps that affect the course of the group's process (Zastrow, Charles. Larry E. Davis 2006), namely: pre-design phase, beginning phase, middle phase and completion phase (Pincus \& Minahan, 1973; Turner, 1978 ; Garvin, 1997; Du Bois \& Milley, 2005; Zastrow, 2006).

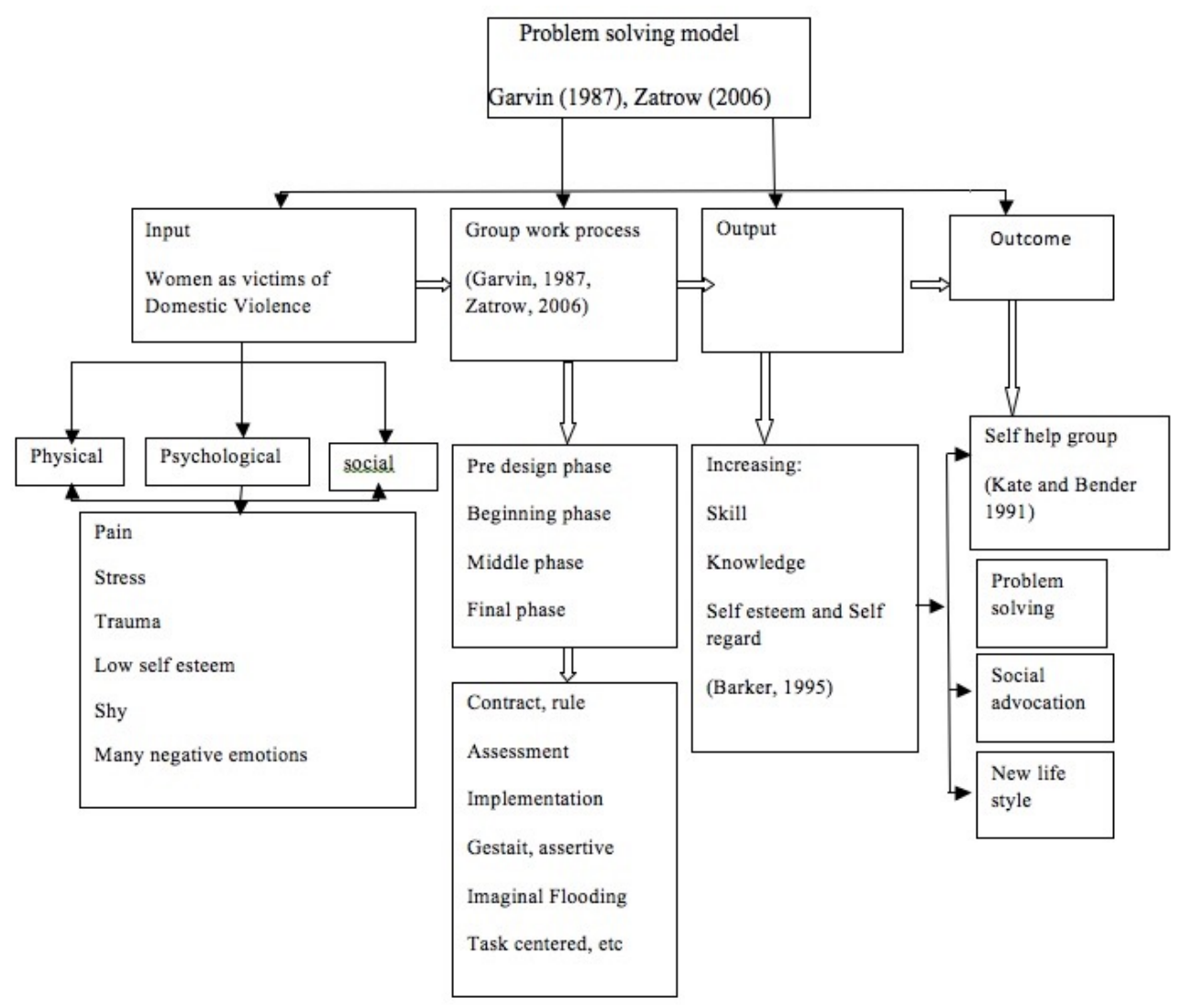

Figure 1 : Research Framework 


\section{Research Methodology}

Research methodology was done by using qualitative method, which is a systematic analysis of the social activity through study subject observation in detail in a setting with the aim to get an understanding and interpretation of how people create and maintaining social world (Mulyana, 2002; Sugiyono, 2007). The type of study conducted in this study was in the form of social action (action research).

\section{Research Subject}

The subjects of this study were six women who had been victims of domestic violence in accordance with predetermined criteria, for more details can be seen in Table 1 .

\section{Objectives and Benefits of Research}

Assessing the extent of social workers intervention, social work group / group therapy, how it can improve the social welfare of domestic violence victim women in the city of Bandung, with the aim in particular to: study profile of domestic violence victim women, observe thoroughly every phase in the group work (phases: pre-design, beginning, middle and completion), design activity in each phase, assess the intervention impact against female victims, and analyze group process work against the practice of Social Work

\section{Research Process}

This research was conducted in twelve (12) sessions of interventions and divided into four stages / phases, namely first phase is the phase of pre design (1 session), which is aimed at choosing of members of the group, the second phase, namely the beginning phase $(2$ sessions $)$ filled with introductions, create rules and assessments. The third phase is the middle phase ( 8 sessions), as implementation of psychosocial therapy, which is based on the assessment results, including the implementation of the technique / therapy: gestalt, cognitive and behavioral. The last phase is the completion phase (1 session), namely evaluation and termination about the future plan discussion.

Collecting data technique in this research is in the form of interviews, observation, focus group discussions (FGD) and psychosocial therapy practice/implementation.

\section{Result and Discussion}

Results showed that study subjects characteristics based on their ages ranging between 24 to 39 years and educational background in which they were not graduated from primary school to high school. While in the aspect of occupation, the results showed that 1 person had stable work, 1 person had freelance work and 4 people were housewives and in general the research subjects had experienced or were victims of domestic violence between 1 to 5 years. All members of the group had physical problems, psychological, social and economic problems as a result of domestic violence they experienced, even one person coupled with sexual violence.

Full picture of the study subject's profile can be seen in the following table: 
Table 1: Group member profile (women experiencing domestic violence)

\begin{tabular}{|c|c|c|c|c|c|c|c|}
\hline Name & $\begin{array}{c}\text { Age } \\
\text { (year) }\end{array}$ & $\begin{array}{c}\text { Last } \\
\text { Education }\end{array}$ & Job & $\begin{array}{c}\text { Age } \\
\text { When } \\
\text { Married }\end{array}$ & $\begin{array}{c}\text { Violence } \\
\text { Background }\end{array}$ & Violence type & $\begin{array}{c}\text { Emotion after } \\
\text { Experiencing } \\
\text { domestic } \\
\text { violence }\end{array}$ \\
\hline $\mathrm{I} \mathrm{k}$ & 25 & $\begin{array}{l}\text { Junior high } \\
\text { school }\end{array}$ & $\begin{array}{l}\text { House- } \\
\text { wife }\end{array}$ & 17 & $\begin{array}{l}\text { Acts of domestic } \\
\text { violence } \\
\text { experienced due } \\
\text { to husband's love } \\
\text { affair, the } \\
\text { husband does not } \\
\text { work and the } \\
\text { involvement of } \\
\text { the family in } \\
\text { matters of the } \\
\text { household. }\end{array}$ & $\begin{array}{l}\text { Physical, } \\
\text { social, } \\
\text { psychological } \\
\text { / psychiatric, } \\
\text { economic and } \\
\text { sexual }\end{array}$ & $\begin{array}{l}\text { Sad, angry, } \\
\text { disappointed, } \\
\text { Stress }\end{array}$ \\
\hline $\mathrm{Wr}$ & 39 & $\begin{array}{l}\text { High } \\
\text { School }\end{array}$ & $\begin{array}{l}\text { House } \\
\text { wife }\end{array}$ & 19 & $\begin{array}{l}\text { Experiencing acts } \\
\text { of domestic } \\
\text { violence because } \\
\text { her husband has a } \\
\text { high temperament } \\
\text { and husband did } \\
\text { not work. }\end{array}$ & $\begin{array}{l}\text { Physical, } \\
\text { social, } \\
\text { psychological } \\
\text { /psychiatric } \\
\text { and economy }\end{array}$ & $\begin{array}{l}\text { Sad, angry, } \\
\text { disappointed, } \\
\text { stressful }\end{array}$ \\
\hline Ys & 32 & $\begin{array}{l}\text { High } \\
\text { School }\end{array}$ & $\begin{array}{l}\text { Entre } \\
\text { preneur }\end{array}$ & 19 & $\begin{array}{l}\text { Acts of domestic } \\
\text { violence } \\
\text { experienced due } \\
\text { to problem of } \\
\text { sexual } \\
\text { intercourse, } \\
\text { overwork. }\end{array}$ & $\begin{array}{l}\text { Physical, } \\
\text { social, } \\
\text { psychological } \\
\text { /psychiatric, } \\
\text { economic and } \\
\text { sexual }\end{array}$ & $\begin{array}{l}\text { Sad, } \\
\text { anger, } \\
\text { disappointment, } \\
\text { stress }\end{array}$ \\
\hline $\mathrm{Im}$ & 37 & SD & $\begin{array}{l}\text { House } \\
\text { wife }\end{array}$ & 19 & $\begin{array}{l}\text { Experiencing acts } \\
\text { of domestic } \\
\text { violence due to } \\
\text { financial problem } \\
\text { (poor). }\end{array}$ & $\begin{array}{l}\text { Physical, } \\
\text { social, } \\
\text { psychological } \\
\text { /psychiatric and } \\
\text { economic }\end{array}$ & $\begin{array}{l}\text { Sad, angry, } \\
\text { disappointed, } \\
\text { stressed, } \\
\text { trauma }\end{array}$ \\
\hline $\mathrm{Nr}$ & 25 & SMK & $\begin{array}{l}\text { House } \\
\text { wife }\end{array}$ & 18 & $\begin{array}{l}\text { Experiencing acts } \\
\text { of domestic } \\
\text { violence due to } \\
\text { different } \\
\text { principle, } \\
\text { financial problem } \\
\text { (poor) and the } \\
\text { husband does not } \\
\text { work. }\end{array}$ & $\begin{array}{l}\text { Physical, } \\
\text { social, and } \\
\text { psychological } \\
\text { /psychiatric }\end{array}$ & $\begin{array}{l}\text { Sad, angry, } \\
\text { disappointed, } \\
\text { stressed, } \\
\text { Trauma }\end{array}$ \\
\hline $\mathrm{Rt}$ & 28 & $\begin{array}{l}\text { Junior high } \\
\text { school }\end{array}$ & $\begin{array}{l}\text { House } \\
\text { wife }\end{array}$ & 18 & $\begin{array}{l}\text { Experiencing acts } \\
\text { of domestic } \\
\text { violence due to } \\
\text { young age } \\
\text { when married and } \\
\text { the husband does } \\
\text { not work, and the } \\
\text { involvement of } \\
\text { the family in } \\
\text { matters of the } \\
\text { household. }\end{array}$ & $\begin{array}{l}\text { Physical, } \\
\text { social, } \\
\text { psychological / } \\
\text { psychiatric and } \\
\text { economic }\end{array}$ & $\begin{array}{l}\text { Sad, angry, } \\
\text { disappointed, } \\
\text { stressed, } \\
\text { depression }\end{array}$ \\
\hline
\end{tabular}




\section{Social Group Intervention with group (Group Work)}

\section{Pre-design phase}

In this phase according to predetermined criteria, there were six (6) subjects of research that will be a member of the group. Besides that in this phase, it was also agreed on various things such as: group rules, place, meeting time, the number of sessions to be followed in this study as well as the needs assessment. The assessment results obtained some things that research subjects need, namely: how to cope with stress/pressure, reduce fear and trauma to their husbands, have the opportunity to support each other with group members and have the skills to tackle various problems, especially with domestic violence.

\section{Beginning Phase}

\section{a) The first and second sessions}

The beginning phase was done through two sessions. First session was intended for introduction of the group members, building trust (trust building) through coaching atmosphere (ice-breaking) in order to create a conducive relationship between them. The second session did further assessment (reassessment) by con ducting focus group discussion about the background of domestic violence they had ever experienced.

\section{Middle phase}

\section{a) Third session}

This phase was done through eight sessions. Each session discussed the items that had been agreed by the expert group members at the beginning of the session. Based on the agreement and understanding between researchers with them, some of the topics that need to be dealt with in this session encompass about; (1) how to deal with a husband who likes misconception; (2) how to express feelings of discomfort, emotion / catharsis; (3) how to deal with such a negative attitude from husband such as a hard stance and he is not responsible; (4) prevent children/others as husband's angers' target; (5) develop skills to run effective communication; (6) how to cope with pressure / stress;(7) how to overcome the trauma of domestic violence and (8) how to keep from being resurfaced domestic violence

\section{b) Fourth session}

Topics discussed in this fourth session, namely how to release emotions and problems faced by members of the group (catharsis). The technique applied by Nourishment techniques of gestalt approach in psychosocial therapy.

According to the observations of researchers and the recognition of group member, this technique is successful for them, it is seen from the expression on their face or expression that looks happy after doing this technique, other than that they felt relieved because all the problems have been issued. Researchers did not find any difficulties in carrying out these techniques and the whole group can run with optimal technique. Other study found that all of member group fully engaged in active condition, they follow with passion even among them can pull out their emotions so they cried.

\section{c) Fifth Session}

The fifth session topics namely: How to confront negative attitudes and behavior of the husband. The bad attitude was aggressive, hard, less responsible and an affair with another woman. The purpose of 
this session is enabling the member group to overcome negative attitudes husband. Techniques used here was Focus Group Discussion (FGD).

FGD results obtained that some types of domestic violence that often done by husband can be divided into 2 categories namely verbal and non verbal. Verbally usually in the form of dirty words, while nonverbal form were punches, kicks, pushing, showing a furious face, bulging eyes, and often the perpetrators of violence throw household furniture to the victim. But all of this was thought to be considered unimportant to be solved or discussed by the group members, they considered this a family disgrace that no one else should know. Facing all that they resigned and just bemoaned his fate. The six group members felt they had no power to act and act appropriately when their husbands committed acts of domestic violence. Through FGD, members of the group realized that their attitudes had been wrong, thus they discussed and shared ways to deal with negative attitudes of their husbands. They also give support to each other and share experiences in dealing with husbands who are considered to behave negatively. Even discussions develop to anyone and any side that can be asked for help when violence is occurring. These sessions also give benefit in self-introspection process of each member of the group, they realize that they are too passive and can't communicate well. This also raises awareness among them to practice effective communication, at least from start to give response and stimulus to the circumstances that happened. In other words this session gives benefits to group members other than as a cathartic process, give each other support and empathy among them as well as a means of self-introspection and able to design activities for the future, i.e. effective communication skills.

\section{d) Sixth Session}

Sixth session discussed about how to prevent anger directed to children/others. The object in this session was members of the group can discuss and talk about the ways that can be implemented so their anger is not targeted to child/someone else after experiencing acts of domestic violence. The technique used was the focus group discussions and role playing.

In this session it was found that group members became more cooperative in expressing their opinions and addressing the problems they faced. In addition, they shared experiences in accordance with the problems they faced. They also provide an alternative that can be used in preventing emotions in order not to trigger to the child / others. Awareness of the wrong emotions consequences in distribution also becomes an interesting subject as this will affect the attitudes and behaviors of their children when they grow older. The benefits and outcomes of this session are they can find some ways to prevent emotions or anger in order not to be vented to other children / people. The ways proposed by members of the group include doing self-introspection, transferring and asking for help to others (close friends or family). In addition, through this session it could be seen that emotional impingement can also be categorized as violence act and it can be imitated by children and other families.

\section{e) The seventh session}

Seventh session topic was enhancing communication skills. The purpose of this session is enabling group work experts discussed and shared ways that can be implemented to develop skills in effective communication. The technique developed was role playing. The results obtained from this session were the group members understand and adept to communicate effectively that they practice in daily activities in the family and neighborhood.

\section{f) Eighth session}

Eighth session is: how to cope with pressure / stress experienced by the expert group.

Based on the needs of the group members to be able to cope with stress/pressure that often happened, they agreed to use Emotional Freedom Technique (EFT) training. Observational study by investigators revealed that the implementation of EFT therapy sessions using this procedure can be followed by all group member, they did tapping process by full feeling and being able to pull out their emotions so they cried. All members of the group said that the feelings become more spacious, lighter, feel more 
sincere and submissive in facing the problems, and considered memorable for the emotion tied up in the thoughts and feelings (catharsis) so they feel better and peaceful.

The experts agreed to periodically perform $E F T$ at their residence and will practice these techniques in accordance with the direction that have been given by the investigators. Investigators therefore consider that this therapeutic process can be a learning process for them and can be done on their own, so that the technique or therapy is beneficial to the group of experts. Besides all the group members seemed happy to run this session, because they had more knowledge and new skills to cope with psychosomatic disorders encountered as a result of problems that happened to them and they agreed to continue to practice this technique through a meeting between them in their residence. In this case, such condition can be seen as opportunities for group members to form a self help group.

\section{g) Ninth Session}

The ninth session topic is How to Cope with Trauma as a result of domestic violence. This topic was chosen by group members who experienced traumatic symptoms due to the violence they experienced. Although not all of them experienced this, but by the group member request, this session is run for all the members in consideration as a learning process for others. Given technique is imaginal flooding as a technique intended to overcome traumatic event. Researchers found that previously traumatized group members can greatly take benefit from the imaginal flooding techniques. This can be observed because group members who practiced this technique look more calm and comfortable at their faces and behavior, as well as from their confessions when asked about their feelings after applying the technique.

\section{h) Session Tenth}

Session tenth topic is how to avoid domestic violence from happening. The purpose of this session is group members can discuss about the way in which the actions of domestic violence will not reappear. This session succeeded in identifying various alternative options for domestic violence not to recur. This session can also be used as a process of evaluation and review of previous sessions, such as: recalling catharsis, overcoming stress, practicing communication skills, assertive and others.

\section{Observation Phase}

This phase consists of two sessions: the first session with the group assessment topic and the second session discuss the future and hope of the group members. This phase is also aimed at answering the objectives of the study concerning the incidence that can be seen from the interventions of social work intervention with the collection in handling the problems of women who experienced domestic violence.

\section{a) Session eleventh}

This session discusses the results of group work assessment/ evaluations that have been carried out. The goal is to find out whether they have learned something useful and what still needs to be studied more to address the problem of domestic violence. The results of the intervention showed that they felt many benefits to overcome the problems caused by domestic violence and they also feel have the skills intended as a solution especially in overcoming their psychosocial problems.

\section{b) The twelfth session}

The twelfth session topic is future plans discussion and the expectations of the group members. The purpose of this session is to discuss what activities will be carried out after the group ends in accordance with their expectations.

The group members agreed to continue this activity by learning and repeating all the skills of various techniques that they have already taught. Besides, they also discuss productive economic 
activities. Group members are divided into two groups according to the interests and talents of each member, i.e. groups that sell snacks and groups that sell phone credit.

\section{Conclusions}

This research has been beneficial for women victims of domestic violence, especially those including research subjects, such as having the ability to expel emotions / problems, to provide learning process, to understand effective communication and have skills in overcoming psychosocial problems experienced. Reduced anxiety, stress, and trauma experienced by the research subject, was seen through the research subject confession and their facial expression, also task completion in accordance with their roles and function in family and society. Besides, the researchers found that the work of this group provides an opportunity for the growth of self-help groups. Katz and Bender (1980) defines selfhelp group as a small group that grow to help each other in achieving a distinctive purpose and voluntary action.

For researchers as social workers, the study can execute / implement role as a therapist through a team approach so that it has a good practical experience, especially in intervention to women victims of domestic violence. Group work method practice also revealed distinctiveness primarily through the stages / phases that implemented.

This research can also be recommended to various competent parties in the handling of women and families in general to provide further intervention for the internal and external environment where women victims of domestic violence are located, including interventions for children and families of victims as well as services for husbands as perpetrators of this domestic violence.

\section{References}

Agustine Dwi Putri. Kompas ed. March 13 ${ }^{\text {th }}$, 2011. Deciding Steps toward Marriage. From http://nasional.kompas.com/read/2011/03/13/04323844/

April Howard, Stephanie Riger, Rebecca CampBell, \& Sharon Wasco. (2003). Counseling Services for Battered Women A Comparison of Outcomes for Physical and Sexual Assault Survivors. Journal of Interpersonal Violence. Vol. 18 No. 7, July, p. 717-734

Barker. (1995). The Social Work Dictionary. New York : Free Pres

Bedard, Marcia.(1990).Domestic Violence:Feminist Responses. NWSA Journal 3(2), 464-475.

Bonnie, Russell \& Max. R. Uhlemann. (1994). Women Surviving an Abusive Relationship: Grief and The Process of Change. Journal of Counseling \& Development.ISSN-0748-9633., Vol 72(4), March-April 1994, 362-367.

Burhanudin \& Esa Nur Wahyuni. (2012). Learning and Teaching Theories. Yogyakarta : AR-Ruzz Media

Cawood D. (1997) Assertive managers are skilled at managing people and effective in communicating. Jakarta: PT. Gramedia Pustaka Utama.

Creswell W. John. (2010). Research Design: Qualitative, Quantitative, and Mixed Approaches. Yogyakarta : Pustaka Pelajar

Cox,J, \& Stoltenberg, C. (1991). Evaluation of A Treatment Program for Battered Wives. Journal of family violence, 6(4), 395-413.

David W. Johnson and Frank P. Johnson. (2006). Joining Together: Group Theory And Group Skill, 3d ed. (Englewood Cliffs, NJ:Practice-Hall, 1987)

Departemen Sosial RI. (2005). Guidelines of Social Assistance for Victims of Domestic Violence at Protection House and Trauma Center.

Egan, G.(1998). The Skilled Helper. USA: Brooks/Cole Publishing company.

Erich Fromm. (2000). The Roots of Violence, Socio-Psychological Analysis of Human Behavior. Yogyakarta: Pustaka Pelajar

Evans, G. W. (2000). Stress and Open-Office Noise. Journal of Applied Psychology, Vol. 85(5):779783. 
Gerald L.Euster. (1980). Group Work in Contemporary Social Work, $2^{\text {nd }}$ ed. Donald Brieland et al. New York: McGraw-Hill

Helen Northen and Roselle Kurland. (2001). Social with Group, $3^{\text {rd }}$ ed. New York: Columbia University press.

Frew, D. R. (1987). Percieved Organizational Characteristics and Personality Measures tas Predictors of Stress/Strain in the Workplace. Journal of Management Winter, 1987 Vol. 13 No. 4 633-646.

Fathur Rahman \& Siti Rohmah Nurhayati.(2006). Gender-based Psychological Mentoring Models in Cases of Violence Against Women. Faculty of Science Education. Yogyakarta State University.

Fitriyati.(2008). Women's Rights are Still Abandoned. Retrieved on December 15 ${ }^{\text {th }}, 2011$ from http://kammiaksi.blogspot.com/2008/04/hak-hak-perempuan-masih-terabaikan.html.

Field.(2003). Self Esteem for Woman. Bandung: Kaifa

Ferroni.(1990). Assortion. Perth: School of Social Work-Curtin University of Technology.

Follette, V. M., Polusny, M. A., Bechtle, A., \&Naugle, A. (1996).Cumulative Trauma: Impact Of Child Sexual Abuse, Sexual Assault, And Spouse Abuse. Journal of Traumatic Stress, 9, 25-35.

Fromm, Errich. (2001). The Roots of Violence, Socio-Psychological Analysis of Human Character. Yogyakarta: Pustaka Pelajar.

Friedlander, W.A. (1977). Concepts and Methods of Social Work. New Delhi: Prentice Hall of India.

Garvin, Charles. (1987). Contemporary Group Work. New Jersey: Prentice Hall-Inc.

George, M.J. (2003). Invisible Touch: Aggression and Violent Behavior. 8,23-60. (A comprehensive review and analysis of female initiated partner aggression. Historical, empirical and case evidence presented to demonstrate reality of "battered husband syndrome").

George, Winfield, \& Blazer, (1992). Sociocultural Factors in Sexual Assault: Comparison of Two Representative Samples of Women. Journal of Social Issues. Volume 48, Issue 1, pp. 105-125, Spring.

Getzel, G. S. (2005). Group Work Service To People With AIDS During A Changing Pandemic. In G. L. Greif \& P. H. Ephross (Eds.), Group work with populations at risk (2 ed.). New York: Oxford University Press, Inc.

Gochros, Harvey.L.(1979). Behavior Change and Modification. Englewood Cliffs.H.J: Prentice.

Hamidahbt.Ab. Rahman \& Hamdan b.Abd.Kadir. (2007.) Intervention Module for Domestic Violence (Child Abuse) and Teen Crimes (Juvana): Suggestions for Approach for Youth and NGO. Haworth Press. 2006. Social Work with Groups, Volume 2009.

Heap, Ken. (1977). Group Theory for Social Workers. New Delhi: Prentice Hall of India.

Herry Koswara, et al. (1999). Garvin tentang Group Work. Bandung: KOPMA STKS

Hollis.F. (1964). Casework: A psychosocial Therapy ( $1^{\text {st }}$ ed). New York: Random House

Hollis.F. (1970). The psychosocial approach to the practice of practice. In. R. Roberts \& $R$ Nee(eds). Chicago University of Chicago press

Hollon, S.D.\& Beck, A.T.(1994). Cognitive and Cognitive Behavior Therapies. In Handbook of Psychothetapy of Behavior Change. New York: Wiley\& sons.

Howard, April.,Stephanie, Riger, Campbell, Rebecca \& Wasco, Sharon. (2003). Journal of Interpersonal Violence, 18(7) 717-734.

Howard, April.,Riger, Stephanie., Campbell, Rebecca., \& Wasco, Sharon. (1995). Counseling Services for Battered Women: A comparison of Outcomes for Physical and Sexual Assault Survivors. Chicago: University of Illinois Press.

Hurlock, E. (1980). Developmental psychology. Jakarta: Erlangga.

J. Moleong. (2004). Qualitative Research. Bandung: PT. Rosdakarya

James, Drever. (1987). Dictionary of Psychology. Jakarta: Bina Aksara

Katz,Alfred. (1981). Self Help and Rehabilitation.Illinois: The Dorsey Press Hall.

Konopka, Gisela. (1954). Group Work the Institution: A Modern Challenge. New York: Association Press

Konopka, Gisela. (1972). Social Group Work: A Helping Process (2 ed). Englewood Cliffs. H.J: Prentice Hall

$\begin{array}{llll}\text { National Women's } & \text { Commission. } & \text { From }\end{array}$ http://repository.upi.edu/operator/upload/s_psi_044444_chapter1.pdf

Kristi Purwandari.(2006). Psychological Reinforcement for Tackling Domestic and Sexual Violences. Jakarta: Program of Women's Studies of Postgraduate Program of Indonesia University. 
Larry E. Davis, Maeda J. Galinsky and Janice H. Schopler.( 1995). RAP A framework for leadership of multiracial groups. Social work 40, no. $2 \mathrm{~s}$

Lazarus, R.s. \& Folkman, S.(1984). Stress, Appraisal and Coping. New York: Springler.

Levitsky \& Perls. (1970). Gestalt Therapy: One of Guidance and Counseling Approaches. Retrieved 17 January 2012 from http://www.belajar konseling.com/berita-164-terapi-gestalt-salah-satupendekatan-bimbingan-dan-konseling.html

LePine, J. A, LePine, \& M.A., Jackson, C. (2004). Challenge and Hindrance Stress: Relationships with Exhaustion, Motivation to Learn, and Lerning Performance. Journal of Applied Psychology, 883-891.

Major, V. S. (2002). Work Time, Work Interference with Family, and Psychological Distress. Journal of Applied Psychology, 427-436.

Mansour Fakih. (2003). Analyses of Gender and Social Transformation. Yogyakarta: Pustaka Pelajar.

Mancoske, R. J, Standifer, D, \&Cauley, C. (1994). The effectiveness of brief counseling services for battered women. Research on Social Work Practice, 4, 53-63.

Marcia Bedard.(2002). Domestic Violence: Feminist Responses. NWSA Journal Vol. 2, No. 3 (Summer, 1990), pp. 464-475. The Johns Hopkins University Press.From :http://www.jstor.org/stable/4316050

Martin Thomas, John Pierson. 1995. Dictionary of Social Work. Jakarta: Gramedia.

Messman-Moore, T, Long, P, \&Siegfried, N. (2000). The Revictimization of Child Sexual Abuse Survivors: An Examination of the Adjustment of Collegewomen with Child Sexual Abuse, Adult Sexual Assault and Adult Physical Abuse. Child Maltreatment: Journal of the American Professional Society on the Abuse of Children, 5(1), 18-27.

Middleman, Ruth.R., \&Gale Goldberg.(1974). Social Service Delivery: A Structural Approach to Social Work Practice. New York: Columbia University Press

Mochamad Ali Mauludin \& Sugeng Winaryanto Syahirul Alim. (2010). Final Report of Research of Young Researchers (LITMUD) of Padjadjaran University: The Role of the Group in Developing the Empowerment of Cattle Breeders in the Southern Region of Tasikmalaya Regency. Bandung: Padjadjaran University.

Moch.Nazir.(1999). Research Method. Jakarta: PT Gramedia.

Mulyana,Deddy. (2003). Qualitative Research Methodology: New Paradigm of Communication Science and Other Social Sciences. Bandung: PT Remaja Rosida Karya.

Nelson Richard \& Jones. (2009). Introduction to counselling skills text and activities 3rd edition. Los Angeles : Sage

Northen H. \& Kurland roselle. (1965). Social Work With Groups. New York: Columbia University

Nur Iman Subono. (2000). State and Violence against Women. Jakata: Charity of Jurnal Perempuan.

Nurma, (2011) Triggers of Domestic Violence. From http://sosbud.kompasiana.com/2012/05/24/pemicu-kekerasan-dalam-rumah-tangga/

Pincus, Allen, \& Minahan, Anne. (1973).Social Work Practice: Model and Method. Illinois: FF Peacock Publisher.

Prasetyono, Dwi Sunar. (2005). Tips for Overcoming Anxiety and Depression. Yogyakarta: TUGU Publisher. p. 11

Prawiroharjo, Sarwono. (1996). Science of Midwifery. Jakarta: Yayasan Bina Pustaka.

Puji Susilowati. (2008). Violence Against Women in Dating Periode. From http://www.epsikologi.com/epsi/individual detail.asp?id=476

Putnam Tong. R. (2006). Feminist Thought: The Most Comprehensive Introduction to the Main Flow of Feminist Thinking. Yogyakarta: Jalasutra

Randall, M, \& Haskings, L. (1995).Sexual Violence in Women's Lives.Violence against Women, 1 (1), 6-31. Ranisa.18 Mei 2012. Live Beautiful with Taqwa. From http://ranisa-hidup-indah-dengantaqwa-ranisa.blogspot.com/2012/05/terapi-gestalt.html

Resnick, H., Kilpatrick, D.,Walsh, C., \& Vernon, L. (1991). Marital rape. in R. Ammerman\& M. Herson (Eds.), Case studies in family violence (pp. 329-353). New York: Plenum.Richard M., Tolman \& Christian E. Molidor.(1998). A Decade of Social Group Work Research: Trends in Methodology, Theory, and Program Development.

Rogers Carl.(1970). Carl Rogers on Encounter Groups. New York : Harper\&Row

Rita Serena Kalibonso. (2006). Journal of Such Discrimination is called Violence against Women. Jakarta: Charity of Jurnal Perempuan 
Routledge. 2010. Social Work With Groups: A Journal of Community and Clinical Practice. ISSN: 0160-9513. 33: 279-281.

Sawitri Supardi. (2008). Marriage with All its Problems, PT Gramedia, Jakarta

Sawitri Supardi .S.,17 November (2008). Trauma in the Childhood and the Future of Children. From http://www.indoforum.org/t62184/

Safwan.(2010). Initial Handling in Social Reality. Retrieved January 1 $7^{\text {th }}$, 2012 from http://safwankita.wordpress.com/2010/10/31/trauma-deteksi-dini-penanganan-awal-di-realitassosial/

Schuler, E. (2002). Definition and Conceptualization of Stress in Organizations. Sage: Thousand Oaks.

S. Friedman, Howard. (2000). Personality: Classic Theories and Modern Research. Pearson: Boston

Shulman, L. (1985). The Dynamics of Mutual Work Aid, Social with Group. USA: Columbia University Press.

Shaffer. B.P. John. And David M Galinsky.(1989). Models of Group Therapy. Prentice Hall: Englewood Cliffs, New Jersey 07632

Scissons, Edward H. (1993). Counseling for results: Principles and practices of helping. Brooks/Cole (Pacific Grove, Calif.) xv, 238 p.

Skidmore, Rex, A.\& Thackeray.(1994). Introduction to Social Work Practice: New York: Prentice Hall Inc.

Skinner,B,F. (1964). Behaviorism at Fifty, In Behaviorsm and Phenomenology, (eds). Chicago: University of Chicago Press.

Sluiter, J. K. (2004). Stressful Work, Psychological Job Strain and Turnover. Journal of Applied Psychology, 442-454.

Soetarto, 2010.Thesis: Self Concept with Conformity to Peer Groups in Clubbing Activity (A Correlation Study on Class XI Students SMA Negeri 1 Purwokerto Who Conducts Clubbing). Faculty of Psychology, Diponegoro University.

Spiritia. (2006b). Sejarah HIV/AIDS. Retrieved March 15 $5^{\text {th }}$ 2009, from http://spiritia.or.id/art/bacaart.php?artno=1030

Sri Wahyuni. (2009). Family Empowerment as a Form of Prevention of Violence Against Women through Gender Equality Innovation. Media Info litkesos, ISSN 0126-3692.33(4), 391-402.

Sugiyono.(2007). Understanding Qualitative Research. Bandung: Alfabeta

Sugiyono. (2007). Qualitative Quantitative Research Methods and R \& D. Bandung: Alfabet.

Surya Mohamad. (2003). Counseling Theories. Bandung: PustakabaniQuraisy.

Sulistyowati Irianto. (2006). Journal of Is the Law Allowed to Take Side, a Woman's Question. Jakarta: Charity of Jurnal Perempuan

Sutardjo A. Wiramihardja.(2004). Clinical Psychology. Bandung: Alfabeta

Tempo Interaktif.(2005). Violence against Women Increases Almost Double. Jakarta: Tempo Interaktif.

Thomson, B. J. (1998). Case Management in AIDS Service Settings. In D. M. Aronstein \& B. J. Thomson (Eds.), HIV and social work: A practitioner's guide. New York: Haworth.

Turner, J. Francis.(1978). Psychosocial Therapy. New York: Macmillan Publishing Co

Tutty, L., Bidgood, B., \& Rothery, M. (1993). Support Groups for Battered Women: Research on Their Efficacy. Journal of Family Violence, 8, 325-343.

Vasquez,D.,\& Falcone, R.(1997). Cross Gender Violenc. Annals of Emergency Medicine, 29(3), 427429.

Wolf, M. S., \& Mitchell, C. G. (2002). Preparing social workers to address HIV/AIDS prevention and detection: Implications for professional training and education. Journal of community Health, 27(3), 165-180.

Wulan Sari, Ajeng. \&Zulkaida, Anita. Relationship between Group Conformity with Achievement Motivation in the End Teenagers http://www.gunadarma.ac.id/library/articles/graduate/psychology/2009/Artikel_10505007.pdf

Yuli Suliswidiawati. (2008). Self Healing By Emotional Freedom Technique. Bandung: Westeria Bureau of Psychological Consultation.

Zastrow, H. Charles. (1982). Introduction To Social Welfare Institution: Social Work Problem Services, and Social Issues. Illinois: The DorseyPress. Homewood. 
Zastrow, H. Charles. (1999).The Practice Of Social Work (7 Ed). USA: Books/ Cole Publishing Company.

Zastrow, H. Charles.(2006). Social Work with Groups: A Comprehensive Workbook (7 ed). USA: Thomson Brooks Cole.

Zakaria, Ibrahim. (2005). Woman Psychology. Bandung: Pustaka Hidayah.

Zakaria, Ibrahim.(2010). Gender-based Violence against Women. Yogyakarta: Rifka Annisa Womens Crisis Center. 